\title{
EAl Endorsed Transactions

\section{Using arcade games to engage students in the learning of foreign and mother languages}

\author{
Adelina Moura ${ }^{1,}$ \\ ${ }^{1}$ Graphics, Interaction and Learning Technologies - GILT, ISEP, Portugal, adelina8@gmail.com
}

\section{Abstract}

It is imperative to continue thinking about and reinventing education because mobile technologies and the Web are redefining where, when and from whom we learn. Authors from different study fields have recognised the multiple possibilities of video games for language learning and for interdisciplinary use. Education can benefit from the potential of these artefacts if properly integrated into the educational process. This article describes a language learning experience based on electronic games - of the ARCADE type. This research has been carried out in order to study the learning of vocabulary, grammar and other school curriculum in Portuguese and French classes, both in Elementary and Vocational Education. The results show that video games have a positive impact on motivation for learning and cognitive development. Students' perceptions show that ARCADE games were helpful in improving vocabulary and language skills. Interest in these games was the same for boys and girls, however further studies are needed.

Received on 22 September 2014, accepted on 26 January 2015, published on 17 March 2015

Keywords: electronic games, video games, serious games, languages learning, curricular learning, mobile learning.

Copyright (C) 2015 Adelina Moura, licensed to ICST. This is an open access article distributed under the terms of the Creative Commons Attribution licence (http://creativecommons.org/licenses/by/3.0/), which permits unlimited use, distribution and reproduction in any medium so long as the original work is properly cited.

doi: $10.4108 / \mathrm{el} \cdot 2.5 . \mathrm{e} 2$

\section{Introduction}

Gaming is a human characteristic and the act of playing is as old as mankind itself. Leisure activities, many with the same features, exist in many different cultures [1]. Thus, games can be considered as an universal activity. The belief that educational games should be a part of children's everyday lives, because they help in children's development, comes from Classical Antiquity. The recognition of the potential of games to aid learning has been expressed long ago, by renowned authors such as Piaget and Vygotsky.

Since the advent of electronic games (EG) ${ }^{1}$ in 1950, because of developments in computer research and the arrival of the microprocessor, we've learnt new ways to play, creating a new cultural form in modern society. The initial success of video games was due to the fact that they combined television with a computer.

\footnotetext{
${ }^{1}$ Throughout the text we use the terms electronic games (EG) and video games as synonyms.
}

In the seventies the first video game in plug-in cartridge format was released. Its success caused some concern in society, about the possible negative effects of video games on children. In the following decades the world saw an increase in microprocessor power and memory capacity and this allowed video game companies to release new, increasingly sophisticated games. The success of video games in the ' 90 s caused an increase in research studies in many fields, such as medicine, sociology, psychology and also in education [2] [3]. The results of these studies, published in journals, books, and other publications, have helped to reassure those parents and educators who were concerned about the perceived potential dangers that video games present to children and adolescents.

Video games are one of the most common ways that children and young people gain access to computer culture. However, games are often criticised and rarely used in educational contexts. Working with video games in school is not an easy task, but they can help get effective results and improvements in learning, particularly for learning vocabulary [4]. Currently, there are many authors who recognise the benefits that electronic games can offer to learning, because of their motivational nature when 
combined with the behaviour of new generations of students [3] [5] [6].

Younger students, called "digital natives" [7] or "the gamer generation" [8], do not know a world without electronic technology. They have grown up surrounded by screens and video games and their lives are highly connected to the world. Different studies have shown that adolescents and young people are already familiar with video games [9] [10].

As far as the potential of video games is concerned, while some parents and educators are critical, by judging them as being a waste of time, there are several arguments in favour of introducing them into educational practices [11] [12]. One of these arguments is that games can help develop higher-order thinking skills, such as problem solving, teamwork and critical thinking [12]. There is evidence, based on studies about the use of educational games, showing that young people's interests in using games in the classroom [9] [12] [13] is because, when learning is linked to play, it becomes more enjoyable and appealing. In this context, serious games are emphasised as a learning tool, and defined as games where education, rather than entertainment, is the primary goal [14]. These types of games allow the creation of engaging, learning experiences to meet specific educational objectives.

There are several free tools to build EG, enabling any teacher to create personalised games which are adapted to the needs of their students. Current research clearly shows that there is a great interest in the educational use of games, in particular, serious games, and this led us to create a set of Web-based video games, targeted at Portuguese and French classes. Through these kinds of games, students are able to assimilate vocabulary and grammar, review content and better understand some of the reading comprehension activities practiced in the classroom.

The experiment presented here was developed in the $2013 / 2014$ academic year, in a combined elementary and secondary public school, in the north of Portugal. Two classes participated in this study, one was $9^{\text {th }}$ grade students studying French as a foreign language and the other was $10^{\text {th }}$ grade students of a Vocational Education course, attending mother-tongue Portuguese classes. Our initial question was "How can we motivate students to engage in learning by the use of video games?" In this study, we view electronic games as resources that can help make learning more interactive and challenging. We took advantage of the facts that young people love to interact with screens and that gameplay heightens their emotions. The electronic games that we created are available in the two class blogs ${ }^{2}$. They help foster pedagogical differentiation, and encourage students to develop their own ways of learning, because the IT environment is multimodal [15].

\footnotetext{
$29^{\text {th }}$ and $10^{\text {th }}$ grade classes blogs: http://8aesca.blogspot.pt/p/jeuxprofessions.html; http://adelina-moura.blogspot.pt/
}

\section{Theoretical approaches to the use of games in education}

Different learning theories have supported research into the use of games in education, especially electronic games. Behaviourism (with theorists such as Pavlov, Thorndike, Watson and Skinner) advocates that learning happens by the reinforcement of stimuli and relevant responses, through rewards. In the behaviourist approach, repetition is the key for learning. This aspect is still valid in the development of basic skills in reading, writing and spelling [16].

Studies developed by Papert [17] [18], based on Piaget's constructivism, emphasise the role of external objects in facilitating the learning process. In the constructivist approach, the student addresses learning activities actively, building a personal representation of knowledge, using physical artefacts. For constructivists the most important thing, when using games for learning, is that the player engages with the material, discusses and reflects on it, and uses it as a means to construct knowledge.

The sociocultural paradigm, which includes a number of theories, has as its principal theorists Vygotsky, Wertsch, Leontjev, Lave and Wenger, although each one introduces a different perspective. In this approach, mediation is a key element to understanding the process of learning, and knowledge is the tool that mediates the activity. Both sociocultural and activity theory (as well as situated learning) perceive activity as being mediated by tools, which may include technology, language, communities, culture and symbols. The sociocultural approach emphasises the role of social interaction through the concept of proximal development [19]. Learning occurs when a teacher, a peer or a tool guides a student from an actual point of development to a point of potential development, each serving as a mediator to generate a feeling of enjoyment of a particular activity. The sociocultural perspective draws attention to the need to consider both the context and the tool when it comes to learning and education issues. This is because different tools and contexts can facilitate a range of different experiences [19] [20] [21].

This author [22] analyses a set of studies on the effectiveness of learning with EG, concluding that these types of games facilitate learning, although there are only a few studies that compare video games with other teaching styles. The author raises the question of what these games offer that differentiate them from other existing educational practices. For this author, each learning theory presents, in its way, an approach to this question.

\section{Learning based on video games}

Game-based learning is a relatively new area of research. Its objects of study are games with the ability to provide some sphere of knowledge that a player can apply in real life. Research focused on video-game-based learning highlights the motivational effects of the method [2] [3]. One of the reasons is that when a person plays this kind of game they are very much involved in it. They become fully 
immersed in the game and can play for hours, forgetting what is around them [23].

Studies on games and motivation show that there is a link between intrinsic motivation and learning [24]. Intrinsic motivation is sustained by individual elements such as challenge, curiosity, control, fantasy, competition, cooperation and recognition and these aspects are present in many video games [7] [22].

For a game to be successful it is important that it raises the curiosity of the player. Some authors [25] noted that curiosity is one of the elements that induce learning. These authors highlight two types of curiosity: sensory (interest originated by new sensations) and cognitive (interest in knowledge).

Technology allows the player to immerse himself in a virtual environment providing highly-motivating learning experiences. If a student is involved and actively interacts with the game, learning will be more effective. Research in the area of games has revealed that learning can be more effective if it is seen as being fun by the learner. According to some authors [26], learning outcomes will improve if educational activities arise in a motivational context. These authors present a theoretical framework for developing video games for learning.

Although there are several learning models, we emphasise a practice model that it is important to understand when studying games [24]. The aim of the practice model is to make suggestions for games design, so that they have features that enable effective learning. This model involves a cycle that includes a player's judgments (interests) and reactions. The model also has a feedback system that allows players to understand both its game aspect and its learning aspect. As the player absorbs new information it's added to their existing knowledge. Based on factors that characterise games, these authors define six major dimensions of games: fantasy, rules and goals, sensory stimuli, challenge, mystery and control.

The author [3] [27] [28] has conducted several studies on video games and learning and presents a set of principles that help us to understand their potential in the learning process. For this author, EG in addition to contributing to learning content, also help to develop the skills necessary in the contemporary world. Video games, in general, help to improve the reflexes, motor skills, initiative and autonomy of players and can be used in an educational context to achieve certain educational goals [6].

This author [29] states that most objects and situations result in some sort of emotional reaction, although some are on a larger scale than others. The artefacts (interactive objects) with which we interact in everyday experiences generate emotions which may or may not be outwardly displayed. For example, video games have the power to generate strong emotions, particularly in the younger generations who are accustomed to playing on computer and mobile devices from an early age.

Video games can be played on consoles, PCs, and on mobile devices. With the advent of mobile devices, particularly smartphones, we see more and more available games, and the amount of time spent on playing games is remarkable. As regards teenagers, they are spending more time consuming media and playing on mobile devices ${ }^{3}$. For most teenagers, the main increase in screen time is in the amount of time spent using mobile phones by texting, accessing social networks, playing games and listening to music. As mobile Internet use becomes more widespread, we can predict that more mobile devices with digital content, including games, will be a part of students learning. Smartphones and other mobile devices are seen as the most popular equipment for inter-generational play and learning. The number of educational games designed for mobile devices increases daily, making learning increasingly ubiquitous.

Game-based mobile learning is becoming progressively common because mobile devices offer support for multimedia content. Nowadays, research in the area of the design and implementation of mobile educational games allows the creation of an engaging, immersive environment. This motivates learning, and can benefit students in many different areas of discipline [44]. Several serious mobile learning games have been developed for different mobile platforms and operating systems such as iOS and Android. Some of them are designed to teach not only skills at the lower levels of Bloom's taxonomy, but also higher level skills, such as analysis, synthesis and critical thinking.

The EG is a form of entertainment that continues to amuse and impassion the young, but they are generally considered by most people to be an out-of-school activity. Both computer games and hand-held video games can be transformed into powerful learning tools [30] because of their motivational potential. A motivated student is what every teacher wants, because she/he shows enthusiasm and interest in activities, is persistent and engages deeply in learning.

\subsection{Profile of video game players}

Who are video games targeted at? Who are the players? To answer these questions, this author [31] responds "everyone". Thus, it is difficult to establish a player profile.

It seems that not all video game players have the same profile [32]. These authors present a classic rating for those players, taking into account the gamer's degree of involvement and the amount of time spent playing, dividing them into "hard-core gamers" and "casual gamers". However, they call attention to the fact that this division is not as linear as it may seem, there are players who can be considered to be hard-core gamers for some games and casual gamers for other games. For these authors, hard-core gamers see video games as their main leisure activity and they seek to obtain the maximum scores. Their main interest is in complex games with difficult goals and they desire to dominate everything related to video gaming. The casual gamers share video gaming with other leisure activities and consequently, share their time and effort equally between

\footnotetext{
${ }^{3}$ According to a 2010 study conducted by the Kaiser Family Foundation.
} 
them all. They prefer popular, economic, and easy video games. Currently, it seems that there is not a single video game player profile, since individuals of different ages play different games with different purposes.

The video games industry has various consumer profiles, and it is important for them to know their customers' preferences and gaming habits, so that they can create games that meet their customers' needs. Parks Associates ${ }^{4}$ has identified six segments of players, who spend one or more hours per month playing on any platform: the power gamers (highly motivated and interested in games, playing on any game devices and spending a great deal of time playing); social gamers (moderately motivated to play, they rarely initiate the game session, they spend some time playing, especially socialising with other players); leisure gamers (moderately motivated, they play to relax or just pass the time); dormant gamers (have little leisure time, spend little time playing, but they like to play occasionally); incidental gamers (have little motivation and interest in games, play to pass the time and focus in specific game types); occasional gamers (they are the segment with lower motivation and interest in video games and spend little time playing). In the report "The Reinvention of Game Consoles" ${ }^{5}$, PA analyses new game consoles and the facilities, such as cloud games services, that are available to gamers. They also predict trends for the interaction between cloud services and future generations of games consoles.

The screen attracts people, and time spent in front of it passes quickly, whether watching a television show, surfing the Internet or watching a movie. The same happens with video games, but with more impact, because the player is part of the action. The gamer can be the protagonist who explores scenarios, makes decisions or avoids being caught by the enemy. Although there is a structure in the game that does not depend on the player, games demand some sort of effort, decision and reasoning and players will always demonstrate their skills and abilities. The game requires concentration, attention, and emotional control from the player [32] and these capacities are also appreciated in the classroom context.

According to research by Latitude $^{6}$, an international research consultancy, videogame players of the future will be dynamic and social individuals who are interested in applying elements of the game to the world around them. This has implications for manufacturers and creates opportunities for them to connect in new ways to other players.

\subsection{Video game categories and addiction}

Video games began to gain popularity with the development of information technology and the success of

\footnotetext{
${ }^{4}$ https://www.parksassociates.com/blog/article/changing-profile-of-the-pcgamer

${ }^{5}$ http://www.parksassociates.com/report/reinvention-game-consoles

6 http://latd.com/wp-content/uploads/2011/08/Latitude-

FutureofGaming.pdf
}

game consoles, which soon became some of the bestselling toys. The growth in sales of personal computers (PCs) helped the gaming market to diversify and innovate products, following players' needs and desires. Today, production of computer games, games consoles, portable consoles and mobile devices is huge and continues to grow. There is a wide and diverse range of styles and products

Gaming is not limited to childhood and schooling age, it is an activity that pervades throughout adulthood to old age. The games market, particularly video games for youths and adults is large and tends to occupy a social role in everyday interaction and entertainment.

The market for video games does not cease to evolve, following the technological trends and the demands of the players. Despite the constant change, many games have common features that allow their categorisation. We highlight the following games typology [31].

\section{Table 1. Video game modalities}

\begin{tabular}{|l|l|l|}
\hline \multicolumn{1}{|c|}{ Game type } & \multicolumn{1}{|c|}{ Features } & \multicolumn{1}{c|}{ Modalities } \\
\hline Arcade games & $\begin{array}{l}\text { Fast paced gameplay } \\
\text { Minimum reaction time } \\
\text { Focused attention } \\
\text { Secondary strategic component }\end{array}$ & $\begin{array}{l}\text { Platforms } \\
\text { Labyrinths } \\
\text { Sports } \\
\text { Shoot and forget }\end{array}$ \\
\hline Simulation games & $\begin{array}{l}\text { Low influence of reaction time } \\
\text { Complex and changing strategies }\end{array}$ & $\begin{array}{l}\text { Instrumental } \\
\text { Situational } \\
\text { Sports }\end{array}$ \\
\hline Strategy games & $\begin{array}{l}\text { The player takes a specific } \\
\text { identity } \\
\text { Only the final goal of the game is } \\
\text { known } \\
\text { Development depends on orders } \\
\text { and objects }\end{array}$ & $\begin{array}{l}\text { Graphic } \\
\text { adventures } \\
\text { Roleplay } \\
\text { War Games }\end{array}$ \\
\hline Table Games & Cards, chess, ping pong, ... & Trivial Pursuit \\
\hline
\end{tabular}

The diversity of video games is great. We can find board games, strategy games, simulations, graphical adventures, role games, among others. Most EGs have the following features. Firstly, most video games simultaneously present textual information, sound, photos, music, animation, video and three-dimensional images. It is often difficult for a player to decode the symbolic information contained in these elements. Secondly, the games are dynamic in nature. By using a computer it is possible to produce images that can create a representation of any reality. Virtual environments and simulations are increasingly sophisticated, providing the user with a feeling of involvement and immersion in the environment that has been created and in the stories that appear on the screen. Finally, video games are clearly interactive, there's two-way communication between player and game, players interact physically and emotionally with the game's environment, their actions can result in the acquisition of game tokens or points, and the game gives them feedback messages. Many EGs can be played in different ways: individually, as a group, online or offline. Some even permit a large number of players at the same time, increasing both the involvement of each participant in the game and the interactivity between the participants. 
Despite the diversity, the most popular video games are always those that exhibit violent content. Early games were of the arcade type, in which the most important thing was reaction time, with a small level of violence. Today, electronic games have acquired high levels of sophistication and extreme violence. Many of these games are played by young and old people and are highlighted by the media. Because of this, the general public often see video games and violence as being synonymous. As yet, however, no valid empirical evidence exists to show that players transfer any of the violence experienced in video games into subsequent real-life violent behaviour.

Besides this aspect, there is some criticism about how video games can cause players to display behaviour patterns of individualism and isolation. What is more, critics consider that children spend too much time with these games. They give them priority over other recreational and sports activities, which are considered to be more appropriate from a social and educational point of view. It is up to families to keep an increased vigilance in case these behaviours start to occur. In contrast, according to [31] EG are beneficial in cognitive aspects such as memory, imagination, creativity and development of intelligence.

Although some controversy and concerns persist, about the possible negative consequences that video games can have on the development and behaviour of children and adolescents, there is no conclusive data. A study by [32], with children and adolescents aged between 10 and 17 years old, reveals that students were highly involved in school activities, with differences associated with gender. Most video game players are boys and they spend more time playing than girls. Moreover, there was no significant difference in the academic performance and personality of game players or non-game players.

According to [26], in order to use computer games as good learning tools, it is important to understand that users are active and motivated while playing the game.

\section{The educational dimension of video games}

Play is a free action that gives pleasure, sometimes in a regulated way, as happens in schools, and sometimes more freely in moments of leisure. As pointed out by [34], with the help of games, children get to know the environment, people and objects that surround them. For [35] and [36] games facilitate the child's growth and progress to the next stage of development, and they have an important role in human development. They are effective tools that accompany the individual in the learning and growth process. Play promotes sociability, and stimulates action, reflection and expression. Through games the individual develops the creative, critical thinking and communication skills which are so important in the digital age.

The world is changing rapidly, imposing a constant overhaul of knowledge and skills required by different areas of society. For students to have future success in the labour market (in some cases, in jobs of the future that do not yet exist), they need mechanisms that enable them to acknowledge their skills and passions, to work on them and direct themselves to be more effective in the future [3]. Educational institutions cannot act separately from the technological age in which we live [37]. Video games are allowing children to enter into the culture of simulation and some educational games try to follow some of their attributes (content and format) to increase students' motivation for school activities. However, it is not easy to transpose computer games into an educational format, due to the specifics of school content and the way to use games in the classroom. For some authors [2] [3] [38] video games are much more than entertainment. For these authors games provide the player with a variety of actions and routines, rules, social interaction, problem and conflict solving, development of cognitive and motor skills and also how to deal with success and failure.

Although we often hear that the new generations of students suffer from concentration problems, this author [38] believes that the issue is not so much the problem of students' attention, but the lack of strategies for teachers to meet students' needs. Today's students want to learn in a different way from the students in the past. They want ways of learning that are meaningful to them. They want to be prepared for the challenges of an uncertain and constantly changing future.

Although the environments of video games are alien to most teachers they are not alien to most students, who are more skilled in the technical field than teachers. For a teacher, it is not the technical field that is the problem. The problem is how to integrate, analyse, and efficiently use video games in order to achieve specific educational goals. By using video games as another resource for learning in the classroom, teacher and students become closer to the real world (where millions of people play video games) and to the culture of the moment.

The term "edutainment" has emerged (a combination of educational use and entertainment) to classify these types of games, in order to indicate some educational aspect to them. The term has been used to give some comfort to parents who buy serious games (providing entertainment and instruction), preferring that their children learn something at the same time as playing. But video games with educational features are not having the expected success.

A crucial issue, when combining play and learning, is that students tend to focus on achieving the game goals and neglect the educational objectives [22]. For this author, an example of this is the game Age of Empires, which presents historically relevant settings and stories. However, the main focus of the game is that the player dominates the game itself in order to beat the opponent, and this is what attracts most of the student's attention while playing. The challenge is for the teacher to be able to find a game that makes learning and playing work well together and not put one against the other. Games used in our study seem to go in this direction, because the better the students know the curriculum content the more chances they have to succeed pass the level and get the best score. 


\subsection{Studies for language learning with video games}

In recent years, some studies on the use of video games in language learning have been carried out, especially with the development of Massively Multiplayer Online Games (MMOG). The fact that this type of game enables players from different parts of the globe to interact through their avatars increases the opportunities for communication and interaction with native speakers. A case study conducted by [39] analyses the potential of learning the Spanish language through the World of Warcraft game. The results suggest that the game's features are beneficial for the development of language learning and socialisation, but more structured studies about introducing MMOG in school are necessary. Both video games and virtual 3D worlds are seen as offering good opportunities for language learning [2].

These authors [4] conducted a study to analyse the learning of foreign languages while students play online games outside of school, paying particular attention to their effectiveness at teaching and learning vocabulary. Another study, developed by [40], examined the use of video games to improve the listening to and reading of the Japanese language and the results indicate an improvement in learning. This author believes that repetition, the help system and game controls had a positive effect on the learning of the Japanese language. Another author [41] conducted a study about learning English as a foreign language using a video game. The results showed that electronic games were beneficial to the learning of vocabulary and that boys are more inclined to learn through video games than girls.

\section{Arcade games and their contribution to learning}

\section{A. ClassTools.net: tools for creating educational games}

ClassTools.net $^{7}$ is an excellent site for teachers and students to create different learning activities using classic arcade games formats. It is free and requires no registration. Currently it provides more than three dozen different, easy to use templates, enabling any teacher to create flash games for students. In addition, games created by other teachers from different disciplines are also available. This platform is very intuitive; just follow the instructions on the screen. It allows teachers to create online electronic games that can provide excellent learning opportunities for different curricula or can reinforce knowledge that has already been gained. The games created in ClassTools.net can easily be shared via email or included in a blog or website using the embedded code. The games can be saved in HTML format on the computer, but they always need Internet access in order to be played. Classtools.net is a simple and fun way to

\footnotetext{
${ }^{7}$ http://www.classtools.net/
}

get students to use their mobile devices to continue learning outside of school. These games are basic (retro-style), but can be used with any kind of topic. To create the EG used in our study, we selected the free, basic version. For those who do not want adverts popping up, and who want to have an area where they can organise and edit all the resources they've created or want to see games in full-screen mode, there is an optional premium (i.e. paid-for) version.

There is a consensus in different learning theories that students learn faster when they are more involved and have fun. In this sense, Classtools.net's portal offers opportunities to design games, quizzes and diagrams that can succeed in the classroom for any subject. It is possible to create games to develop skills in reading, writing, attention and logic or troubleshooting in a more fun and playful way. The games presented in this text were created with the Arcade Game Generator.

\section{B. Arcade Game Generator Formats}

The Arcade is a kind of video game [6], based on platform and fight games, such as Pacman, Mario, Sonic, etc. The Arcade Game Generator offers five formats for the creation of word-based versions of these classic computer games. We decided to create one game in each format. Our aim was to encourage the learning of vocabulary in both the mother tongue and in a foreign language. We also wanted to include more difficult curricula themes, such as "Poetic Text". The games are described here:

- Matching Pairs is a concentration game which helps develop memory by associating pairs of cards. The player needs to turn cards over in order to find matching pairs of questions and answers. If a matching pair is selected they remain exposed, but if there is no match, they are concealed again. After turning the first card, the student needs to be able to find its partner. At first this has to be done by random guesswork, but as more cards become exposed, the player needs to remember their contents and positions. The objective is to match all the pairs in the shortest possible time. Students obtain positive or negative feedback from the game saying whether the selected second card is correct or not.

- Wordshoot is a "shoot-em-up" game. Questions or definitions appear at the bottom of the screen and, with the help of a mouse-controlled gun-sight, the student "shoots" the correct answer for each question. For each level, the player is allowed 60 seconds and has a maximum of 20 shots. At the end of each round (determined when either all the correct answers have been shot, or time has expired or all the ammunition has been used) the player's score reflects a combination of correct answers, unused time and remaining ammunition. The game gradually becomes more challenging at each level, with targets moving in different directions and at different speeds, meaning that the player needs to become more efficient in order to progress through the levels. This is one of the most addictive features of games and is already validated in the gaming world. Wordshoot also has very satisfying and appealing sound effects. This has been the format that students most prefer, considering it the most fun and most efficient for learning. 
One aspect that made this format most appreciated by students is the fact that at the start it's easier to get to the higher levels, but the difficulty level, and therefore the challenge, increases as the student learns the curricula contents or vocabulary. This makes students feel more technically proficient and also more confident about their knowledge of languages, enabling them to respond better to questions in the game.

- Flashcards is a key tool to aid memory, because students can see if they have really assimilated the subject. Students can challenge themselves or they can play with a partner. Two cards are displayed, one representing questions and the other, answers. By repeated clicking, a player can make a selection from the available question cards. They, or their partner, then has to try to figure out the answer that is concealed "under" the other, face-down card.

- Manic Miner is a "platform" game similar to the original Mario series. It is a maze that requires multiple levels of player expertise. Questions appear at the bottom of the screen and a choice of answers move around in the playing area. To score points the player has to manipulate the character Wally the miner, to make him walk or jump to the correct answers while avoiding the wrong answers.

- Cannonball Fun is a demanding game, as it requires more skills to play than other formats, and can be rewarding if the player has more time to play. Questions appear at the bottom of the screen and the correct answer is among several that are displayed in the playing area. The player must learn to carefully position a cannon then set its angle of trajectory and determine the correct force needed in order to make the cannonball land on the correct answer. This format has not been popular with the students in this study.

With these five game formats, as shown in Figure 1, the teacher can challenge students to show what they know collaboratively, in a fun and entertaining way, but the most important thing is that, in order to be successful at the games, students need to know the subject well.

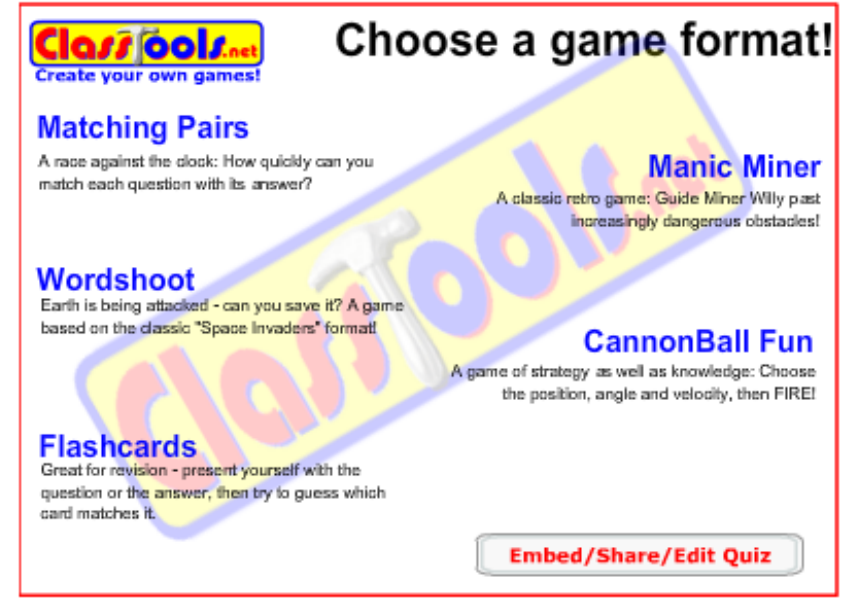

Figure 1. The five Arcade game formats available in the generator

\section{Vocabulary and content learning with video games}

Learning vocabulary in both foreign languages and the mother tongue presents some challenges for teachers and students. Often, students find it difficult to memorise a lot of words and they get bored in class. So the teacher needs to find new strategies to reverse this situation and video games can help [4].

Because games attract the players' attention and creativity [39], these resources become ideal for integration into education. Video games are attractive to students because they entertain, and are interactive and communicative. For students, the playing of online games improves language learning, especially vocabulary skills [4]. While they are playing, students forget that they are studying. They engage in the activity and participate more in class.

The number of games that teachers have at their disposal, for use in the language classroom, is huge. For example: skill, competition, collaboration, simulation or association games. With these games students can deduce rules, learn a customised lexicon [5] and do work relating to: the definitions of words, deduction of synonyms and antonyms, grammar structures, oral and written communication, etc. The teacher has to decide which type of game is most appropriate to achieve the educational goals of a particular subject and context.

When using video games at school, it is important that the teacher clearly states the aims of the game, so that students understand that it is an integral part of the learning process, not a moment of fun and leisure. There are not many video games which are designed specifically for the language classroom, although some can be adapted to this purpose. The teacher must find the best solutions so that students feel that the games which are used in classroom are useful, attractive and are high quality from the point of view of improving language learning. Figure 2 shows a screenshot from the first level of Wordshoot, one of our games for learning French vocabulary.

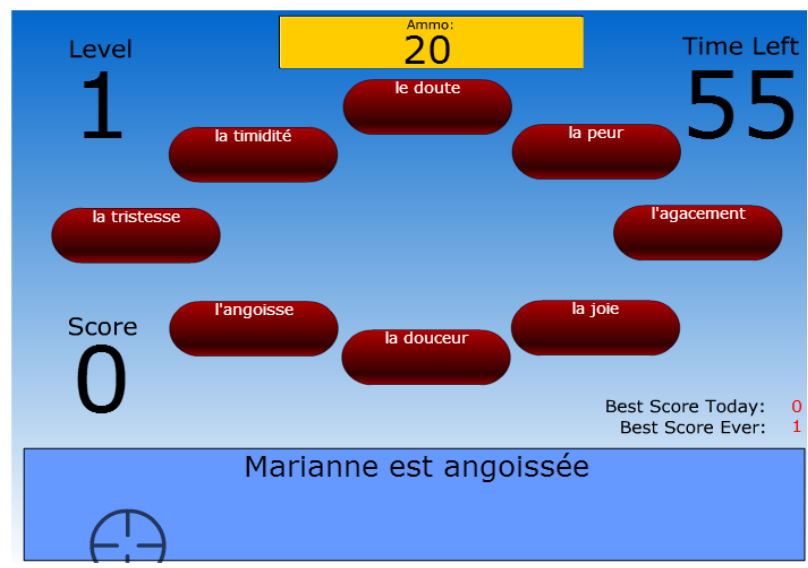

Figure 2. An example of our games to learn vocabulary 
Some of the advantages of using electronic games in the classroom, as an aid for both the teaching and learning of vocabulary or other class content, relate to the fact that games are fun. They turn the classroom into a more dynamic place and encourage students to win. For being successful, students gain some recognition from the teacher or their classmates, and this motivates them to play. In addition, games add something new to the class because they bring playful elements, and allow the review of themes or topics that have been covered in class. Games need the player to adopt different strategies when using their visuospatial, kinetic and auditory skills. Games also need to be suited to the different learning styles of individual students (active and reflective, intuitive and sensory, visual and verbal, sequential and global, inductive and deductive).

Video games normally use the English language. When young people play, they need to know the appropriate vocabulary for the different situations that are presented to them. Multiplayer games allow them to play in teams, connecting students and providing an environment of familiarity [39]. This facilitates the inclusion of the most timid students and helps the learning of foreign languages. Moreover multiplayer games encourage participation, negotiation and increased learning. Video games create an environment which is mostly learner-centred, and they provide good opportunities for learning, socialisation and competitiveness.

Because games are highly motivating and can cause addictive behaviour, there are some concerns about the pressure to win, which, in some players, can lead to feelings of anxiety. There is also the fact that some students may see games as being a waste of time.

At what point of the lesson should games be introduced? Games can be integrated at any time during the lesson. They should be seen as one more resource that the teacher has available at the time that they do their course preparation. On their part, students have to understand the usefulness of games and their relevance when integrated into the classroom. So, games can be used at any time during the lesson, either for the entire duration or just at specific moments.

\section{Study description}

Taking into account the psychological aspects involved in language learning, video games contribute to actions that can be considered of both a behavioural and a constructivist nature. For example, language-learning video games allow repetition (behaviourism) together with the use of processes of adaptation and organisation of thought (constructivism). To validate the study presented here, we followed the social constructivist approach (collaboration and interaction). We also included aspects of repetition and reward from the behaviourist approach, in which extrinsic motivation (reward and scores given by the game) promotes intrinsic motivation. These elements are present in arcade games such as those we have used in this study.
This is an exploratory case study [42], which was carried out during the 2013/2014 academic year, in a Portuguese, public, combined elementary and secondary school. It took a qualitative methodological approach with some quantitative data analysis. Our goal was to understand the students' perceptions (level of interest and motivation) about the use of arcade-type electronic games to learn vocabulary and other curriculum content in both mother tongue and foreign language classes. To analyse this problem we set three objectives. First, to observe how involved students were with the games while playing individually and collectively. Second, to assess how much games can contribute to the learning process, and third, to enhance the use of mobile devices for educational play both inside and outside the classroom.

Data was collected by using a three-part questionnaire. The first part, concerning the IT profile of students, was answered before the study started. The second and third parts were answered at the end of study. The second part related to the students' perceptions about the integration of EGs in educational practices. The third refers to students' preferences regarding the games. To achieve the objectives outlined in the second part of the questionnaire, we established five criteria, these being attitude, cognitive development, usefulness, game interface and students' expectations about the electronic games that we created. This questionnaire was adapted from other questionnaire surveys [43].

The first part of the questionnaire includes multiple choice questions. The second part uses a Likert scale with three options (agree, undecided, disagree) to indicate the degree of agreement or disagreement with statements. The third part contains open-response questions to collect information about the students' game preferences.

Participants in our study were students from two classes. One was a class in the $9^{\text {th }}$ grade taking French lessons. It comprised 27 students aged between 14 and 15 years old (52\% male and $48 \%$ female). The other was a class in the $10^{\text {th }}$ grade taking vocational, mother-tongue, Portuguese lessons. It consisted of 19 students aged between 15 and 17 years ( $84 \%$ male and $16 \%$ female).

Our video games are designed specifically for educational proposes and are in line with the content of each academic subject. Learning vocabulary, either in the native or a foreign language, is often considered tedious by students and they have a low motivation to learn. Video games have the potential for engaging the students' interest, thereby promoting learning. We made sure that the students understood that the EGs themselves were not what mattered, and that what was more important was that they could learn curricular content in a more active, entertaining and attractive way. We also sought to motivate the students during the games, in order to keep their enthusiasm high, thus encouraging everyone to participate. It was also our concern to ensure that the game formats were appropriate for each class profile. The arcade games are very simple and their rules and structure were easily understood by the students. 
Using arcade games to engage students in the learning of foreign and mother languages.

\section{Data analysis}

\subsection{Ownership of IT equipment and Internet access}

In order to learn if students were able to play outside of the classroom, we asked some questions about whether or not they have IT equipment and Internet access at home (Table 2).

Table 2. Ownership of IT equipment and Internet access $(\mathrm{N}=46)$

\begin{tabular}{|c|c|c|c|c|c|}
\hline \multirow{3}{*}{ Questions } & & \multicolumn{4}{|c|}{ Participants } \\
\hline & & \multicolumn{2}{|c|}{$\begin{array}{c}9^{\text {th }} \text { grade } \\
(n=27)\end{array}$} & \multicolumn{2}{|c|}{$\begin{array}{c}1^{\text {th }} \text { grade } \\
(n=19)\end{array}$} \\
\hline & & f & $\%$ & f & $\%$ \\
\hline \multirow{2}{*}{$\begin{array}{l}\text { Do you have a computer at } \\
\text { home? }\end{array}$} & Yes & 27 & 100 & 19 & 100 \\
\hline & No & 0 & 0 & 0 & 0 \\
\hline \multirow{2}{*}{$\begin{array}{l}\text { Do you have Internet access } \\
\text { at home? }\end{array}$} & Yes & 26 & 96 & 18 & 95 \\
\hline & No & 1 & 4 & 1 & 5 \\
\hline \multirow{2}{*}{$\begin{array}{l}\text { Do you have a mobile } \\
\text { phone? }\end{array}$} & Yes & 27 & 100 & 19 & 100 \\
\hline & No & 0 & 0 & 0 & 0 \\
\hline \multirow{2}{*}{$\begin{array}{l}\text { Does your mobile phone } \\
\text { have Internet access? }\end{array}$} & Yes & 21 & 78 & 17 & 89 \\
\hline & No & 6 & 22 & 2 & 11 \\
\hline \multirow{2}{*}{ Do you have a tablet? } & Yes & 14 & 52 & 7 & 37 \\
\hline & No & 13 & 48 & 12 & 63 \\
\hline
\end{tabular}

As shown in Table 2, all students in both classes have computers at home and only one student in each class doesn't have Internet access, which could be a temporary situation. All students have mobile phones, with $78 \%$ of $9^{\text {th }}$ grade and $89 \%$ of $10^{\text {th }}$ grade students owning phones that have Internet access. As regards tablet ownership, $52 \%$ of $9^{\text {th }}$ grade and $37 \%$ of $10^{\text {th }}$ also have these devices.

\subsection{Game preferences}

It is common to see students playing games on public transport or on the street using their mobile devices. Therefore, we wanted to know which games are normally played by the students who participated in this study.

Table 3. Games played by students

\begin{tabular}{|l|c|c|c|c|c|c|c|}
\hline \multirow{2}{*}{ Games } & \multicolumn{2}{|c|}{ Classes } & \multicolumn{5}{c|}{ Equipment used to play } \\
\cline { 2 - 9 } & $\mathbf{9}^{\text {th }}$ & $\mathbf{1 0}^{\text {th }}$ & PC & PSP & $\begin{array}{c}\text { Smart } \\
\text { phone }\end{array}$ & Tablet & Wii \\
\hline Diversion & $\mathrm{X}$ & & & & $\mathrm{X}$ & $\mathrm{X}$ & \\
\hline Pou & $\mathrm{X}$ & & & & $\mathrm{X}$ & $\mathrm{X}$ & \\
\hline $\begin{array}{l}\text { Subway } \\
\text { Surfers }\end{array}$ & $\mathrm{X}$ & $\mathrm{X}$ & & & $\mathrm{X}$ & $\mathrm{X}$ & \\
\hline Candy Crush & $\mathrm{X}$ & & $\mathrm{X}$ & & $\mathrm{X}$ & $\mathrm{X}$ & \\
\hline MiniCraft & $\mathrm{X}$ & $\mathrm{X}$ & $\mathrm{X}$ & & $\mathrm{X}$ & $\mathrm{X}$ & \\
\hline Flow Free & $\mathrm{X}$ & $\mathrm{X}$ & & & $\mathrm{X}$ & $\mathrm{X}$ & \\
\hline $\begin{array}{l}\text { Hill-Climb } \\
\text { Racing }\end{array}$ & $\mathrm{X}$ & & & & $\mathrm{X}$ & $\mathrm{X}$ & \\
\hline Lep'sWorld & $\mathrm{X}$ & & & & $\mathrm{X}$ & $\mathrm{X}$ & \\
\hline
\end{tabular}

\begin{tabular}{|l|c|c|c|c|c|c|c|}
\hline \multicolumn{1}{|c|}{ Games } & \multicolumn{2}{|c|}{ Classes } & \multicolumn{5}{c|}{ Equipment used to play } \\
\hline LOL & $\mathrm{X}$ & & $\mathrm{X}$ & & & & \\
\hline FIFA 14 & $\mathrm{X}$ & $\mathrm{X}$ & $\mathrm{X}$ & $\mathrm{X}$ & & & \\
\hline Millionaire & $\mathrm{X}$ & & & & $\mathrm{X}$ & $\mathrm{X}$ & \\
\hline Angry Birds & $\mathrm{X}$ & & $\mathrm{X}$ & & $\mathrm{X}$ & $\mathrm{X}$ & \\
\hline Super Mario & $\mathrm{X}$ & & & & & & $\mathrm{X}$ \\
\hline Call of Duty & $\mathrm{X}$ & $\mathrm{X}$ & & $\mathrm{X}$ & & & $\mathrm{X}$ \\
\hline $\begin{array}{l}\text { Olympic } \\
\text { Games }\end{array}$ & $\mathrm{X}$ & & & & & & $\mathrm{X}$ \\
\hline Farmville & $\mathrm{X}$ & & $\mathrm{X}$ & & & & \\
\hline NBA 2K14 & $\mathrm{X}$ & & $\mathrm{X}$ & & & & \\
\hline Criminal Case & $\mathrm{X}$ & & $\mathrm{X}$ & & & & \\
\hline Blockz & $\mathrm{X}$ & & $\mathrm{X}$ & & & $\mathrm{X}$ & \\
\hline $\begin{array}{l}\text { Ages of } \\
\text { Empires }\end{array}$ & $\mathrm{X}$ & & $\mathrm{X}$ & & & & \\
\hline $\begin{array}{l}\text { NBA Live } \\
\text { 2008 }\end{array}$ & $\mathrm{X}$ & & $\mathrm{X}$ & & & & \\
\hline PES & $\mathrm{X}$ & $\mathrm{X}$ & $\mathrm{X}$ & $\mathrm{X}$ & & $\mathrm{X}$ & \\
\hline $\begin{array}{l}\text { League of } \\
\text { legends }\end{array}$ & $\mathrm{X}$ & $\mathrm{X}$ & $\mathrm{X}$ & & & & \\
\hline Mario Karts & $\mathrm{X}$ & & & & & & \\
\hline Guitar Hero & $\mathrm{X}$ & & & & & & \\
\hline Rifle Master & & $\mathrm{X}$ & $\mathrm{X}$ & & & & \\
\hline GTA & & $\mathrm{X}$ & $\mathrm{X}$ & $\mathrm{X}$ & & & \\
\hline CS & & $\mathrm{X}$ & $\mathrm{X}$ & & & & \\
\hline Gran Turismo & & $\mathrm{X}$ & $\mathrm{X}$ & & & & \\
\hline $\begin{array}{l}\text { My Talking } \\
\text { Tom }\end{array}$ & & $\mathrm{X}$ & & & $\mathrm{X}$ & & \\
\hline Mead soccer & & $\mathrm{X}$ & & & $\mathrm{X}$ & $\mathrm{X}$ & \\
\hline Cross fire & & $\mathrm{X}$ & $\mathrm{X}$ & & & & \\
\hline Need for speed & & $\mathrm{X}$ & $\mathrm{X}$ & & & & \\
\hline Raw 2011 & & $\mathrm{X}$ & & $\mathrm{X}$ & & & \\
\hline $\begin{array}{l}\text { Cards and } \\
\text { Poker }\end{array}$ & & $\mathrm{X}$ & & & & $\mathrm{X}$ & \\
\hline Euro Track & & $\mathrm{X}$ & $\mathrm{X}$ & & & & \\
\hline $\begin{array}{l}\text { New Star } \\
\text { Soccer }\end{array}$ & & $\mathrm{X}$ & & & $\mathrm{X}$ & & \\
\hline Resident Evil & & $\mathrm{X}$ & & $\mathrm{X}$ & & $\mathrm{X}$ & \\
\hline $\begin{array}{l}\text { The Walking } \\
\text { Dead }\end{array}$ & & $\mathrm{X}$ & & $\mathrm{X}$ & & $\mathrm{X}$ & \\
\hline Tomb Raider & & $\mathrm{X}$ & & $\mathrm{X}$ & & $\mathrm{X}$ & \\
\hline Flow colors & & $\mathrm{X}$ & $\mathrm{X}$ & & & & \\
\hline
\end{tabular}

From the data presented in Table 3 we can see that the PC remains the most widely used equipment for gameplay. However smartphones and tablets are more often used by the $9^{\text {th }}$ graders. The most commonly used mobile devices to play video games outside the classroom were smartphones and tablets. A study conducted in Portugal [45] about the games most played by students from primary to higher education, shows similar results. Although the PC is the most frequently used equipment for playing games, the number of people using the smartphone is very close to the number using PCs. Regarding the games that students play most, it was found that some of our students also have preferences for the most popular games.

We wanted to know what general aspects of games are more valued by our students. Table 4 shows the most popular aspects of EGs, categorised by each group participating in this study. 
Table 4. Most valued aspects of general video games

\begin{tabular}{|l|l|}
\hline \multicolumn{1}{|c|}{$\mathbf{9}^{\text {th }}$ grade } & \multicolumn{1}{c|}{$\mathbf{1 0}^{\text {th }}$ grade } \\
\hline Dynamism & Action and adventure \\
Animation & Good Graphics \\
Fun & Fun \\
Timing & A good story \\
Levels and score & Levels and difficulties \\
Action & \\
Complexity & \\
Interactivity & \\
\hline
\end{tabular}

As shown in table 4, several students mention that they appreciate games that challenge them, that present levels, time limits, scores, and difficulties and that have some degree of game complexity. Some students explain this preference by saying that complex and difficult games motivate and inspire them more; they have more fun and become more excited and emotional. The games are challenging and increase the students' adrenaline levels. During play, students only think about getting through the game, they are always looking for more enjoyment. These data are in line with [18, p 4.], when he says:

"Two big lessons I have learned from computer games (...). The first, which I have already noted, is echoed by kids who talk about "hard fun" and they don't mean it's fun in spite of being hard. They mean it's fun because it's hard. Listening to this and watching kids work at mastering games confirms what I know from my own experience: learning is essentially hard; it happens best when one is deeply engaged in hard and challenging activities".

Consoles and mobile devices have become the preferred games platforms. This led us to find out which mobile devices the students used to play games outside the classroom.

Table 5. Mobile device used to play games outside school

\begin{tabular}{|l|r|r|r|r|}
\hline \multirow{2}{*}{ Mobile device } & \multicolumn{2}{|c|}{$\mathbf{9}^{\text {th }}$ grade (n=27) } & \multicolumn{2}{c|}{$\begin{array}{c}\mathbf{1 0}^{\text {th }} \text { grade } \\
(\mathbf{n = 1 9})\end{array}$} \\
\cline { 2 - 5 } & \multicolumn{1}{|c|}{ f } & \multicolumn{1}{c|}{$\%$} & \multicolumn{1}{c|}{ f } & \multicolumn{1}{c|}{$\%$} \\
\hline Smartphone & 14 & 61 & 12 & 63 \\
\hline Tablet & 9 & 39 & 7 & 37 \\
\hline
\end{tabular}

The data presented in Table 5 show that most students in both groups played outside school using their smartphone $\left(61 \%\right.$ in the $9^{\text {th }}$ grade and $63 \%$ in the $\left.10^{\text {th }}\right)$. These data are consistent with the data presented in Table 2, because all students have a mobile phone or smartphone and this device is always with the students and they can play anytime and anywhere. All students of both groups reported having played the class blog's arcade games at home a few times.

We also wanted to know the students' perception of the use of video games as an aid to the learning of the class curriculum.
Table 6. Students perceptions of the use of video games in the classroom $(\mathrm{N}=46)$

\begin{tabular}{|c|c|c|c|c|c|}
\hline \multirow[t]{2}{*}{ Item } & \multirow[t]{2}{*}{ Scale } & \multicolumn{2}{|c|}{$\begin{array}{c}\mathbf{9}^{\text {th }} \text { grade } \\
(n=27)\end{array}$} & \multicolumn{2}{|c|}{$\begin{array}{c}10^{\text {th }} \text { grade } \\
(n=19)\end{array}$} \\
\hline & & f & $\%$ & $\mathbf{f}$ & $\%$ \\
\hline \multirow{3}{*}{$\begin{array}{l}\text { Using electronic games increases } \\
\text { my commitment to class materials. }\end{array}$} & Disagree & 2 & 7 & 0 & 0 \\
\hline & Undecided & 8 & 30 & 4 & 21 \\
\hline & Agree & 17 & 63 & 15 & 79 \\
\hline \multirow{3}{*}{$\begin{array}{l}\text { I like to use electronic games in } \\
\text { class. }\end{array}$} & Disagree & 1 & 4 & 0 & 0 \\
\hline & Undecided & 4 & 15 & 1 & 5 \\
\hline & Agree & 22 & 81 & 18 & 95 \\
\hline \multirow{3}{*}{$\begin{array}{l}\text { These electronic games are useful } \\
\text { for learning. }\end{array}$} & Disagree & 1 & 4 & 0 & 0 \\
\hline & Undecided & 7 & 26 & 1 & 6 \\
\hline & Agree & 19 & 70 & 17 & 94 \\
\hline \multirow{3}{*}{$\begin{array}{l}\text { I prefer to answer questions in } \\
\text { electronic games rather than in the } \\
\text { course book. }\end{array}$} & Disagree & 2 & 7 & 2 & 11 \\
\hline & Undecided & 7 & 36 & 6 & 32 \\
\hline & Agree & 18 & 67 & 11 & 58 \\
\hline \multirow{3}{*}{$\begin{array}{l}\text { Using electronic games increases } \\
\text { my motivation to learn the subject. }\end{array}$} & Disagree & 1 & 4 & 0 & 0 \\
\hline & Undecided & 7 & 26 & 5 & 26 \\
\hline & Agree & 19 & 70 & 14 & 74 \\
\hline \multirow{3}{*}{$\begin{array}{l}\text { These electronic games are } \\
\text { challenging. }\end{array}$} & Disagree & 3 & 11 & 0 & 0 \\
\hline & Undecided & 9 & 36 & 5 & 26 \\
\hline & Agree & 15 & 53 & 14 & 74 \\
\hline \multirow{3}{*}{$\begin{array}{l}\text { Using these electronic games } \\
\text { makes class content easier to } \\
\text { understand. }\end{array}$} & Disagree & 0 & 0 & 1 & 5 \\
\hline & Undecided & 12 & 44 & 5 & 26 \\
\hline & Agree & 15 & 56 & 13 & 68 \\
\hline
\end{tabular}

Regarding the students' perceptions of the use of EGs in the classroom (Table 6 ), $63 \%$ of the $9^{\text {th }}$ grade students and $79 \%$ of $10^{\text {th }}$ grade students agree that games increase their commitment to class materials. The vast majority of students in both groups $\left(81 \%\right.$ in the $9^{\text {th }}$ grade and $94 \%$ in the $\left.10^{\text {th }}\right)$ like playing EGs in class and considers that they are useful for learning $\left(70 \%\right.$ in the $9^{\text {th }}$ grade and $94 \%$ in the $\left.10^{\text {th }}\right)$. Regarding, the preference between answering questions related to class topics in games or in the course book, $67 \%$ of $9^{\text {th }}$ graders and $58 \%$ of $10^{\text {th }}$ graders would rather answer questions using EGs. As regards motivation, $70 \%$ of $9^{\text {th }}$ graders and $74 \%$ of $10^{\text {th }}$ graders agree that games help to increase their motivation to learn. Most students agree that the video games created by the teacher are challenging $(53 \%$ in the $9^{\text {th }}$ grade and $74 \%$ in the $10^{\text {th }}$ ) and make school topics easier to learn $\left(56 \%\right.$ in the $9^{\text {th }}$ grade and $68 \%$ in the $\left.10^{\text {th }}\right)$.

Table 7. Students attitude toward the use of video games in the classroom $(\mathrm{N}=46)$

\begin{tabular}{|l|l|r|r|r|r|}
\hline Items & Scale & \multicolumn{2}{|c|}{$\mathbf{9}^{\text {th }}$ grade } & \multicolumn{2}{|c|}{$\begin{array}{c}\mathbf{1 0}^{\text {th }} \text { grade } \\
(\mathbf{n = 1 9}\end{array}$} \\
\cline { 3 - 6 } & & \multicolumn{1}{|c|}{$\mathbf{f}$} & \multicolumn{1}{c|}{$\mathbf{\text { f }}$} & $\mathbf{\%}$ \\
\hline With electronic games I can learn & Disagree & 2 & 7 & 1 & 5 \\
better by myself. & Undecided & 8 & 30 & 2 & 11 \\
& Agree & 17 & 63 & 16 & 84 \\
\hline With electronic games I can learn & Disagree & 1 & 4 & 1 & 5 \\
at my own pace. & Undecided & 9 & 33 & 0 & 0 \\
& Agree & 17 & 63 & 18 & 95 \\
\hline Electronic games give me the & Disagree & 3 & 11 & 0 & 0 \\
flexibility to select the place where & Undecided & 8 & 30 & 7 & 37 \\
I learn. & Agree & 16 & 59 & 12 & 63 \\
\hline With electronic games it is easy to & Disagree & 2 & 7 & 2 & 11 \\
choose the time when I learn. & Undecided & 11 & 41 & 10 & 53 \\
& Agree & 14 & 52 & 7 & 37 \\
\hline
\end{tabular}


Regarding students' opinions on the use of EGs in class (Table 7), the majority of the students in both groups $(63 \%$ and $84 \%$ ) considers that with EGs the student might learn better by themselves and at their own pace $\left(63 \%\right.$ in the $9^{\text {th }}$ grade and $95 \%$ in the $10^{\text {th }}$ ). As for finding out if EGs allow more flexibility for students to choose the place to learn, $59 \%$ of $9^{\text {th }}$ grade students and $63 \%$ of $10^{\text {th }}$ graders agree that they do. When we asked students if using EGs makes it easier to choose the time to learn $52 \%$ of $9^{\text {th }}$ graders but only $37 \%$ of $10^{\text {th }}$ graders agree. $53 \%$ of $10^{\text {th }}$ graders were undecided. These data are interesting, because some students access these games on their mobile devices (smartphones or tablets), which is why they feel it's more flexible and easy to learn the subject outside school, no matter what the location and time [43] [46]. This shows that students have started to integrate mobile learning into their regular habits. They take advantage of the internet access available on their mobile devices in order to learn at anytime and anywhere [47].

Table 8. Students cognitive development and video games use in classroom $(\mathrm{N}=46)$

\begin{tabular}{|c|c|c|c|c|c|}
\hline \multirow[t]{2}{*}{ Items } & \multirow[t]{2}{*}{ Scale } & \multicolumn{2}{|c|}{$\begin{array}{c}9^{\text {th }} \text { grade } \\
(n=27)\end{array}$} & \multicolumn{2}{|c|}{$\begin{array}{c}10^{\text {th }} \text { grade } \\
(n=19)\end{array}$} \\
\hline & & f & $\%$ & f & $\%$ \\
\hline $\begin{array}{l}\text { Including class topics in video } \\
\text { games encourages to learn } \\
\text { complicated topics. }\end{array}$ & $\begin{array}{l}\text { Disagree } \\
\text { Undecided } \\
\text { Agree }\end{array}$ & \begin{tabular}{r|}
2 \\
11 \\
14
\end{tabular} & $\begin{array}{r}7 \\
41 \\
52\end{array}$ & $\begin{array}{r}1 \\
1 \\
17\end{array}$ & $\begin{array}{r}5 \\
5 \\
89\end{array}$ \\
\hline $\begin{array}{l}\text { The video games challenge to learn } \\
\text { the topics studied. }\end{array}$ & $\begin{array}{l}\text { Disagree } \\
\text { Undecided } \\
\text { Agree }\end{array}$ & $\begin{array}{r}3 \\
8 \\
16\end{array}$ & $\begin{array}{l}11 \\
30 \\
59\end{array}$ & $\begin{array}{r}0 \\
3 \\
16\end{array}$ & $\begin{array}{r}0 \\
16 \\
84\end{array}$ \\
\hline
\end{tabular}

As regards students' cognitive development and the use of EGs to learn (Table 8$)$, most students $\left(52 \%\right.$ of $9^{\text {th }}$ grade and $89 \%$ of $10^{\text {th }}$ graders) agree that the way subject topics are placed in video games encourages them to learn complicated issues, and that these kinds of video games challenge them to learn the topics (59\% and 84\%). These results show that the French class students were more critical with regards to the two items. This aspect should be analysed further in future studies.

Table 9. Classroom benefits of the use of video games $(n=46)$

\begin{tabular}{|c|c|c|c|c|c|}
\hline \multirow[t]{2}{*}{ Items } & \multirow[t]{2}{*}{ Scale } & \multicolumn{2}{|c|}{$\begin{array}{c}9^{\text {th }} \text { grade } \\
(\mathbf{n}=27)\end{array}$} & \multicolumn{2}{|c|}{$\begin{array}{c}1^{\text {th }} \text { grade } \\
(n=19)\end{array}$} \\
\hline & & $\mathbf{f}$ & $\%$ & $\mathbf{f}$ & $\%$ \\
\hline \multirow{3}{*}{$\begin{array}{l}\text { These video games are useful } \\
\text { because the content relates to } \\
\text { school subjects. }\end{array}$} & Disagree & 0 & 0 & 2 & 11 \\
\hline & Undecided & 2 & 7 & 2 & 11 \\
\hline & Agree & 25 & 93 & 15 & 79 \\
\hline \multirow{3}{*}{$\begin{array}{l}\text { These video games, used outside } \\
\text { the classroom, allow me to study in } \\
\text { my free time. }\end{array}$} & Disagree & 1 & 4 & 2 & 11 \\
\hline & Undecided & 6 & 22 & 4 & 21 \\
\hline & Agree & 20 & 74 & 13 & 68 \\
\hline
\end{tabular}

As far as the benefits of video games are concerned (Table 9), the vast majority of students in both groups $(93 \%$ of $9^{\text {th }}$ graders and $79 \%$ of $10^{\text {th }}$ graders) agree that these games are useful because they relate to the subjects studied in lessons, and also because students can study when they have free time ( $74 \%$ and $68 \%$ ). Students are benefiting from the opportunity to access these educational resources through their mobile devices, by taking advantage of their features of mobility, flexibility and portability [43] [46] [39] [47].

Table 10. Student expectations of video game usage in the classroom $(n=46)$

\begin{tabular}{|l|l|r|r|r|r|}
\hline \multicolumn{2}{|c|}{ Items } & \multicolumn{2}{c|}{$\begin{array}{c}\mathbf{9}^{\text {th }} \text { grade } \\
(\mathbf{n = 2 7})\end{array}$} & \multicolumn{2}{c|}{$\begin{array}{c}\mathbf{1 0}^{\text {th }} \text { grade } \\
(\mathbf{n = 1 9})\end{array}$} \\
\cline { 2 - 6 } \multicolumn{2}{|c|}{} & \multicolumn{1}{c|}{$\mathbf{f}$} & \multicolumn{1}{c|}{ f } & \multicolumn{1}{c|}{} \\
\hline I would like to have more & Disagree & 1 & 4 & 1 & 5 \\
opportunities to learn using & Undecided & 6 & 22 & 2 & 11 \\
electronic games. & Agree & 20 & 74 & 16 & 84 \\
\hline I would like to learn other subjects & Disagree & 3 & 11 & 1 & 5 \\
with electronic games. & Undecided & 10 & 37 & 3 & 16 \\
& Agree & 14 & 52 & 15 & 79 \\
\hline
\end{tabular}

As regards students' expectations relating to video games used in the classroom (Table 10), the majority of students from both groups want more opportunities to learn through games $\left(74 \%\right.$ of $9^{\text {th }}$ graders and $84 \%$ of $10^{\text {th }}$ graders). As regards their desire to learn other subjects with EGs, 52\% of $9^{\text {th }}$ grade students and $79 \%$ of $10^{\text {th }}$ graders agree. Note that $37 \%$ of $9^{\text {th }}$ graders were indecisive, possibly because they have never had this experience in other classes.

Table 11. Game interface $(N=46)$

\begin{tabular}{|c|c|c|c|c|c|}
\hline \multirow[t]{2}{*}{ Items } & \multirow[t]{2}{*}{ Scale } & \multicolumn{2}{|c|}{$\begin{array}{c}9^{\text {th }} \text { grade } \\
(n=27)\end{array}$} & \multicolumn{2}{|c|}{$\begin{array}{c}1^{1^{\text {th }} \text { grade }} \\
(\mathrm{n}=19)\end{array}$} \\
\hline & & $\mathbf{f}$ & $\%$ & f & $\%$ \\
\hline \multirow{3}{*}{$\begin{array}{l}\text { The video game interface is } \\
\text { simple. }\end{array}$} & Disagree & 0 & 0 & 0 & 0 \\
\hline & Undecided & 0 & 0 & 0 & 0 \\
\hline & Agree & 0 & 100 & 19 & 100 \\
\hline \multirow{3}{*}{$\begin{array}{l}\text { I didn't need much time to learn } \\
\text { how the game works. }\end{array}$} & Disagree & 1 & 4 & 2 & 11 \\
\hline & Undecided & 6 & 22 & 4 & 21 \\
\hline & Agree & 20 & 74 & 13 & 68 \\
\hline \multirow{3}{*}{$\begin{array}{l}\text { When the game has more levels it } \\
\text { motivates me to play. }\end{array}$} & Disagree & 0 & 0 & 1 & 5 \\
\hline & Undecided & 2 & 7 & 0 & 0 \\
\hline & Agree & 25 & 93 & 18 & 95 \\
\hline \multirow{3}{*}{$\begin{array}{l}\text { I like games that impose time } \\
\text { limits at each level. }\end{array}$} & Disagree & 11 & 41 & 4 & 21 \\
\hline & Undecided & 12 & 44 & 6 & 32 \\
\hline & Agree & 4 & 15 & 9 & 47 \\
\hline
\end{tabular}

We wanted to know if the video game interface (Table 11), did or did not interfere with the performance and motivation to play these games both in and beyond the classroom. All students of both classes agreed that the interface of these EGs is simple and they do not need much time to learn how it works $\left(74 \%\right.$ of $9^{\text {th }}$ grade and $68 \%$ of $10^{\text {th }}$ grade). Regarding the existence of levels, the vast majority of students (93\% and 95\%) likes games with different levels because they feel it makes them more motivated by the game. With respect to time limits imposed at each level, there was not as much agreement, so $44 \%$ of the French class students, show indecision and $41 \%$ do not appreciate 
games that have time limits, such as in the Wordshoot and Manic Miner game formats. In the Portuguese class, $47 \%$ agree and $32 \%$ were undecided.

We believe that it is relevant to study this matter further in order to identify which aspects of video games the students enjoyed best, when played both inside and outside of the classroom.

Table 12. Aspects of video games that are most appreciated by students

\begin{tabular}{|c|c|}
\hline $9^{\text {th }}$ grade & $10^{\text {th }}$ grade \\
\hline 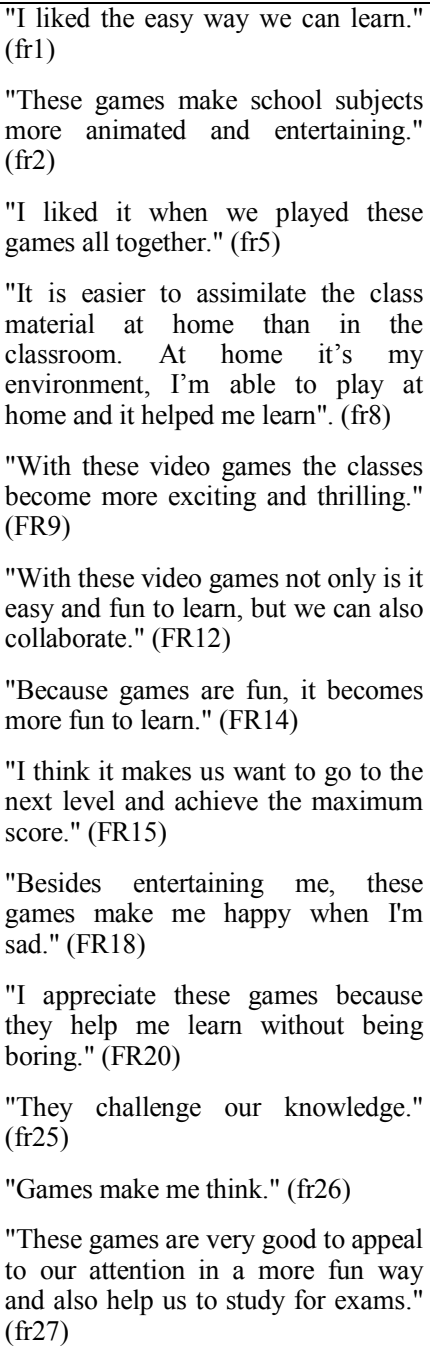 & $\begin{array}{l}\text { "Games make it easier to memorise } \\
\text { some difficult ideas." (port2) } \\
\text { "Repetition helps me memorise, and } \\
\text { understand the main ideas." (port5) } \\
\text { "In these video games we can ask } \\
\text { questions about what we are } \\
\text { learning at school." (port6) } \\
\text { "I wish all class subjects also } \\
\text { included video games." (port10) } \\
\text { "I agree with these games at school, } \\
\text { I think that many students would be } \\
\text { more motivated for class subjects." } \\
\text { (port11) } \\
\text { "I find it very interesting that games } \\
\text { can be used to study." (port12) } \\
\text { "These games are good for } \\
\text { motivation and are more } \\
\text { challenging than traditional } \\
\text { classes." (port13) } \\
\text { "I memorise school topics better } \\
\text { with these games." (port15) } \\
\text { "I adored those games with levels, } \\
\text { because we wanted to play a lot to } \\
\text { finish the game and so we were } \\
\text { obliged to repeat the school topics." } \\
\text { (port18) }\end{array}$ \\
\hline
\end{tabular}

Students' opinions (Table 12) confirm some of the theoretical approaches presented in the literature review, relating to aspects of socialisation, collaborative work and how to learn through games in more fun and motivating ways. These data are consistent with the general video game features that are most valued by the students in Table 4 .

We emphasise that we have observed that learning vocabulary is no longer hard work. After this intervention plan, most of the students increased the number of words they assimilated and improved their results in the second test. These data require a more rigorous study in the future.

\section{Conclusion}

School students are used to playing at home, and feel a need for the playful and challenging aspect of games in educational settings. Therefore, EGs are receiving attention from experts and educators. Although there are studies that show that video games can help achieve educational or curricular objectives and facilitate curricula topics, they are still seen by society as only simple entertainment.

Data presented in this text indicate that these kind of games attract student interest and are valued by students as a tremendous resource to support learning. The data also show that video games can be suitable for learning more difficult or less appreciated subjects, such as grammar or poetry. Using electronic games can be one of the solutions to increase the motivation and engagement of students for learning, because they are related to the subjects studied in class. In addition, students can study when they have some free time to play on their mobile devices, taking advantage of their devices and time, reducing the classroom boundaries and so learning can happen anywhere and anytime.

The most appreciated arcade game format by students participating in this study was Wordshoot, because as the student becomes more knowledgeable, the game becomes more challenging. The vast majority of the students considered that games motivate them more when they have levels, because competition is a powerful element to the success of these games.

This is not a comparative study, but the research highlights some interesting conclusions regarding the motivation and competition fields. In the future we intend that, (i) the students create their own arcade games for their peers, thus converting them into content producers, and (ii) we would like to analyse the different levels of knowledge acquired (vocabulary and grammar) through a control group. As this is primarily a case study, the results confined to this particular case only.

The work presented here, regardless of the interesting results, was a relevant element in our professional training. Not only with regards to the above mentioned theoretical aspects, but in particular, regarding the practice developed in the classroom. This experiment was good for us as a teacher and for our practices of teaching students. We believe that the use of video games in education should be taken into consideration during the preparation of curricula for future generations of students in the 21 st century. With this study we hope to contribute to the development of knowledge in an emerging and controversial area.

This topic requires more empirical studies in order to achieve the following. First, help to reduce uncertainty as to the kind of games that can be integrated into an educational context. Second, to determine the best ways of integrating mobile devices into learning, and third, to foster more discussion about the use of video games in education 
These studies are needed because working with video games in school is not an easy task. If educational games explore motivational scenarios and attractive environments, in which students feel challenged, they will end up feeling attracted by the playfulness of games, and eventually they will adopt these tools in order to support their learning.

\section{Acknowledgements}

Research developed for GILT / ICTWays LLP Comenius ICTWays 528103-LLP-1-2012-1-EN-COMENIUS-CNW.

\section{References}

[1] HUIZINGA, J. (1984) Homo ludens. Madrid: Alianza.

[2] GEE, P. (2007) Good Video Games + Good Learning: Collected Essays on Video Games, Learning and Literacy. New York: Peter Lang.

[3] SQUIRE, K. D. (2011) Video Games and Learning - Teaching and Participatory Culture in the digital age. New York: Teachers College, Columbia University.

[4] TURGUT, Y., \& IRGIN, P. (2009) Young learners' language learning via computer games. Procedia Social and Behavioral Sciences, 1(1), 760-764.

[5] W. C. CHANG \& Y. M. CHOU, (2008) Introductory C Programming Language Learning with Game-Based. Digital Learning. ICWL.

[6] P. M. GRAELLS, (2001) Los Videojuegos: las claves del êxito. Enciclopedia Virtual de Tecnologia Educativa. Online http://peremarques.pangea.org/videojue.htm

[7] PRENSKY, M. (2001) Digital natives, digital immigrants, Part II: Do they really think differently? On the Horizon, 9(6), 1-9.

[8] BECK, J. C., \& WADE, M., (2004) Got game. How the gamer generation is reshaping business forever. Boston, MA: Harvard Business School Press.

[9] PEREIRA, L. (2007) Os videojogos na Aprendizagem: estudo sobre as preferências dos alunos do $9^{\circ}$ ano e sobre as perspectivas das editoras. Dissertação de Mestrado. Braga: Universidade do Minho.

[10] LENHART, A., JONES, S. \& MACGILL, A. (2008) Adults and video games: Report: Gaming, Families, Teens. Pew Internet \& American Life Project Teens. [online] http://goo.gl/yCBcxz

[11] PRENSKY, M. (2006) Don't Bother Me, Mom - I'm Learning. ... are Preparing Your Kids for 21st Century Success - and How You Can Help! St. Paul, Paragon House.

[12] GEE, J. P. (2008) Learning and games. In K. SALEN et al. (Org.), The ecology of games: connecting youth, games, and learning. Macarthur foundation series on digital media and learning Cambridge, MA: The MIT Press, p. 21-40.

[13] MAGALHÃES, H. (2009) A criança e os videojogos: estudo de caso com alunos do $1{ }^{\circ}$ Ciclo do Ensino Básico. Dissertação de Mestrado. Braga: U. Minho.

[14] Michael, D. R. \& Chen, S. L. (2005) Serious Games: Games That Educate, Train, and Inform. Muska \& Lipman/Premier-Trade.

[15] BROWN, H. D. (2007) Teaching by principles: an interactive approach to language pedagogy, 3. ed. San Francisco: Pearson Education.

[16] GOOD, T. L., \& BROPHY, J. E. (1990) Educational Psychology: A Realistic Approach. Fourth Edition. New York: Longman.

[17] PAPERT, S. (1980) Mindstorms: Children, Computers, and Powerful Ideas. New York: Basic Books.

[18] PAPERT, S. (1998) Does Easy Do It? Children, Games and Learning. Game Developer. [online] http://www.papert.org/articles/Doeseasydoit.html
[19] VYGOTSKY, L. (1978) Mind in Society: The Development of Higher Psychological Processes. Cambridge, MA: Harvard University Press.

[20] VYGOTSKY, L. (1986) Thought and Language. Cambridge, Massachusetts: MIT Press.

[21] WERTSCH, J.V. (1991) Voices of the mind: A sociocultural approach to mediated action. Cambridge, MA: Harvard University Press.

[22] EGENFELDT-NIELSEN S. (2006) Overview of Research on the Educational Use of Video Games. Kompetanse, Digital,Vol. 1, pp. 184-213.

[23] SHAFFER, D. (2006) How Computer Games Help Children Learn. New York: Palgrave Macmillan.

[24] GARRIS, R., AHLERS, R., \& DRISKELL, J. E. (2002) Games, motivation, and learning: a research and practice model. Simulation \& Gaming, 33(4), 441-467.

[25] MALONE T.W. \& LEPPER M.R. (1987) Making learning fun: a taxonomic model of intrinsic motivations for learning. In Aptitude, Learning, and Instruction: III. Cognitive and Affective Process Analysis (eds R.E. Snow \& M.J. Farr), pp. 223-253. Erlbaum, Hillsdale, NJ.

[26] MUSTAQUIM, M., NYSTRÖM, T. (2012) An Inclusive Framework for Developing Video Games for Learning. 6th European Conference on Games Based Learning, pp.346-355. [online] http://issuu.com/acpil/docs/ecgbl2013-issuu_vol_2/49/

[27] GEE, J. P. (2003) What video games have to teach us about learning and literacy. New York: Palgrave Macmillan,

[28] GEE, J. P. (2004) Situated language and learning: a critique of traditional schooling. London: Routledge, 2004.

[29] DAMÁSIO, A. (2001) O Sentimento de Si. Lisboa: Publicações Europa-América, $12^{\mathrm{a}}$ ed.

[30] PRENSKY, M. (2002) What Kids Learn That's POSITIVE From Playing Video Games. [online] http://goo.gl/vQZVmC

[31] ESTALLO MARTÍ, J. (1997) Psicopatología y Videojuegos. Instituto Psiquiátrico. Madrid. [online] http://www.ub.es/personal/videoju.htm

[32] JUÁREZ, A. G., MOMBIELA, T. V. (2007) Los videojuegos. Barcelona: Editorial.

[33] JARIEGO, R.L. \& LÓPEZ, M.J. (2003) Los 3adolescentes y los videojuegos.
[online] http://www.cop.es/delegaci/andocci/files/contenidos/vol21 1 5.pdf

[34] MORALES, E. (2009) El uso de los videojuegos como recurso de aprendizaje en educación primaria y Teoría de la Comunicación. In Diálogos de la Comunicación, $\mathrm{n}^{\circ} 78$. [online] http://www.dialogosfelafacs.net/wp-content/uploads/2012/01/80revista-dialogos-videojuegos-en-educacion-primaria.pdf

[35] BRUNER, J. (1984) Acción, pensamiento y lenguaje. Madrid. Alianza.

[36] ROGOFF, B. (1993) Aprendices del pensamiento. El desarrollo cognitivo en el contexto social. Barcelona, Paidós.

[37] GONZÁLEZ, R.C.M. (2011) Los juegos electrónicos como recurso didáctico para el aprendizaje en formación cívica y ética en cuarto grado de educación primaria. [online] http://goo.gl/2qoNaO

[38] PRENSKY, M. (2010) Teaching Digital Natives. Partnering for real learning. Thousand Oaks: Corwin.

[39] RAMA, P. S., BLACK, R. W., VAN ES, E. \& WARSCHAUER, M. (2012) Affordances for second language learning in World of Warcraft. ReCALL, 24, pp 322-338.

[40] DEHAAN, J. W. (2005) Acquisition of Japanese as foreign language through a baseball video game. Foreign Language Annals, 38(2), 278282.

[41] VAHDAT, S., CHAMRAN, S. (2013) The Effect of Video Games on Iranian EFL Learners' Vocabulary Learning. In The Reading Matrix, Vol. 13, $\mathrm{N}^{\circ} 1$.

[42] YIN, R. (2003) Case Study Research: Design and Methods. Thousand Oaks: Sage Publications.

[43] MOURA, A. (2010) Apropriação do Telemóvel como Ferramenta de Mediação em Mobile Learning: Estudos de Caso em Contexto Educativo. Tese de Doutoramento. Braga: Universidade do Minho. [online] http://goo.gl/UuHxqE/ 
[44] PARSONS, D; PETROVA, K; HOKYOUNG, R (2011) Designing mobile games for engagement and learning. The 7 th International Conference on Information Technology and Applications (ICITA). [online] http://www.icita.org/journal/papers/nz-parsons.pdf/

[45] CARVAlHo, A., A, ARAÚJO, I., C, ZAGAlO, N., TIAGO GOMES, T., BARROS, C., MOURA, A., CRUZ, S. (2014) Os jogos mais jogados pelos alunos do Ensino Básico ao Ensino Superior. In Ana Amélia A. Carvalho, Sónia Cruz, Célio Gonçalo Marques, Adelina Moura, Idalina Santos (orgs), Atas do 2.o Encontro sobre Jogos e Mobile Learning. Braga: CIEd, pp. 23-37.

[46] MOURA, A. (2014) Mobile learning: para potenciar os dispositivos móveis dos alunos. Novas Edições Acadêmicas. [online] http://goo.gl/2iRJSm/

[47] WEST, D. M. (2013) Mobile learning: Transforming education, engaging students, and improving outcomes. Washington, DC: Brookings Institution Press. 